\title{
Respon Pertumbuhan Dan Produksi Tanaman Terung (Solanum melongena) Pada Berbagai Jenis Tanah Dan Penambahan Pupuk NPK Phonska
}

\author{
Fitrianti $^{1}$, Masdar ${ }^{2}$, Astiani $^{3}$ \\ Program Studi Agroteknologi, Fakultas Ilmu Pertanian, Universitas Al Asyariah Mandar \\ FitriantiDzulfikar@gmail.com
}

\begin{abstract}
Abstrak
Salah satu upaya yang telah dilakukan untuk peningkatan pertumbuhan dan produksi Terung adalah dengan penambahan pupuk NPK Ponska. Pemupukan berimbang merupakan syarat pokok keberhasilan dalam meningkatkan produktifitas tanaman terung. Salah satu upaya dengan mencari dosis yang tepat. Tujuan dari penelitian untuk mengetahui pengaruh kombinasi dosis pupuk $\mathrm{N}, \mathrm{P}, \mathrm{K}$ terhadap pertumbuhan dan hasil tanaman terung, dan untuk mendapatkan dosis pupuk NPK yang paling tepat dalam meningkatkan produktifitas. Penelitian ini bertujuan untuk mengetahui pengaruh pupuk NPK Ponska terhadap pertumbuhan dan produksi tanaman Terung. Penelitian ini menggunakan Rancangan Acak Kelompok Faktorial. Faktor pertama adalah jenis tanah yang terdiri atas 3 jenis tanah ( berpasir, berhumus dan berliat) dan faktor kedua adalah pemberian pupuk NPK Phonska terdiri atas 3 taraf (5, 10 dan $15 \mathrm{~g} / \operatorname{tanaman})$, setiap perlakuan diulang sebanyak 3 kali. Parameter yang diamati meliputi tinggi tanaman, jumlah daun, jumlah cabang, umur berbunga, umur panen, jumlah buah dan berat buah. Hasil penelitian menunjukkan bahwa pemberian pupuk NPK Phonska tidak memberikan pengaruh nyata terhadap parameter pengamatan tinggi tanaman, jumlah daun, jumlah cabang, umur panen, jumlah buah dan berat buah, namun pemberian pupuk NPK Phonska $15 \mathrm{~g} /$ tanaman memberikan pengaruh nyata pada parameter umur berbunga tanaman terung.
\end{abstract}

Keywords : Terung; jenis tanah, pupuk NPK Phonska

\section{Pendahuluan}

Berbagai upaya telah dilakukan untuk peningkatan produksi tanaman terung seperti penggunaan Terung (Solanum melongena) adalah jenis sayuran yang sangat populer dan disukai oleh banyak orang karena rasanya enak khususnya dijadikan sebagai bahan sayuran atau lalapan.

Selain itu terung juga mengandung gizi yang cukup tinggi, terutama kandungan Vitamin A dan Fosfor. Komoditas terung ini cukup potensial untuk dikembangkan sebagai penyumbang terhadap keanekaragaman bahan sayuran bergizi bagi penduduk. Menurut Sunarjono (2013), bahwa setiap 100 gr bahan mentah terung mengandung 26 kalori, 1 gr protein, 0,2 gr hidrat arang, $25 \mathrm{IU}$ vitamin A, 0,04 gr vitamin B dan 5 gr vitamin C. Selain itu, terung juga mempunyai khasiat sebagai obat karena mengandung alkaloid, solanin dan solasodin.

Menurut BPS Indonesia (2014) dan Direktorat Jenderal Hortikultura (2014), produksi terung nasional sebanyak 557.040 ton dengan luas panen 50.875 ha.Upaya peningkatan produksi terus dilakukan baik melalui intensifikasi maupun ekstensifikasi.Agar pertumbuhan dan produksi tanaman meningkat maka tanah harus cukup mengandung unsur hara dalam bentuk yang dapat diserap oleh tanaman.Kapasitas tanah untuk menyediakan unsur hara bagi pertumbuhan tanaman relative terbatas dan tergantung pada jenis dan sifat tanah, dan keadaan ini sering menimbulkan masalah dalam pertumbuhan dan produksi tanaman.Untuk mengatasi hal tersebut maka perlu dilakukan kandungan unsur hara tanah melalui pemberian bahan organikdan pupuk organik yang dapatmemperbaikisifatfisik, kimiadanaktivitasjasadrenikdalamtanah (Anonim, 2003).

Salah satu usaha untuk meningkatkan produksi adalah denganpemupukan dan pengendalian hama dan penyakit.Dalam usaha budidaya tanaman obat, faktor yang mempengaruhi pertumbuhan tanaman adalah media tanam. Penggunaan media tanam yang tepat akan memberikan kondisi lingkungan yang optimal bagi pertumbuhan tanaman. Media tanam yang baik memiliki kemampuan menyediakan air dan udara yang optimum. Menurut Thompson dan Troeh (1978) komposisi tekstur, struktur dan kandungan bahan organik di dalam suatu media menentukan baik tidaknya suatu media tanam. Hartman dan Kester (1983) menambahkan bahwa media tanam yang ideal harus memiliki syarat mempunyai aerasi dan drainase yang baik kelembaban cukup, bebas dari organisme dan bahan berbahaya, cukup hara dan bobot ringan.

Menurut De Boodt dan Verdonck (1972) media tumbuh yang ideal untuk tanaman dalam wadah pada umumnya harus mengandung ruang pori total sebanyak $85 \%$ volume, ruang yang dapat ditempati udara $25-35 \%$ dan air yang mudah tersedia bagi tanaman sekitar 20$30 \%$ volume.

Memelihara dan memperbaiki kesuburan tanah dengan memberikan unsur atau zat hara ke dalam tanah dapat menyumbangkan bahan makanan pada tanaman. Pemupukan juga akan memperbaiki $\mathrm{pH}$ tanah dan memperbaiki lingkungan tanah sebagai tempat tumbuh tanaman. (Sarief, 1986). 
Selanjutnya dikatakan bahwa pemupukan yang sesuai dengan unsur hara tanah dapat meningkatkan kesuburan kimiawi tanah sehingga sesuai dengan kebutuhan tanaman. Pemupukan bisa dilakukan dengan pemberian pupuk buatan dan pupuk alam atau pupuk organik. Pupuk buatan dapat dibagi kedalam pupuk tunggal dan pupuk majemuk. Pada waktu ini pupukpupuk majemuk lengkap yang ditawarkan mempunyai jumlah kadar total yang jauh lebih tinggi, yaitu antara $30-60 \%$. Selain dari itu, untuk mengimbangi adanya kebutuhan yang berlainan dari berbagai jenis tanaman dan tipe tanah, sekarang pupuk ini dibuat dalam perbandingan yang bermacam-macam.Perbaikan dalam teknik budidaya tanaman untuk tujuan peningkatan hasil dan mutu sayuran telah banyak dilakukan di dalam dan luar negeri. Untuk mendapatkan hasil tinggi selain memperhatikan syarat tumbuh juga harus diperlukan pemeliharaan yang baik (Farim dkk, 2013).

Menurut Mutia (2011) bahwa pupuk anorganik majemuk 15-15-15 (Phonska) meningkatkan panjang batang dan kadar pati, sedangkan pupuk anorganik Rock Phosphate cenderung menghasilkan jumlah cabang dan bobot brangkasan yang lebih tinggi daripada pupuk anorganik majemuk 15-15-15.

Pemupukan dengan penggunaan pupuk anorganik saja dengan dosis sesuai rekomendasi menghasilkan pertumbuhan dan produksi tertinggi.Pemberian kompos jerami dengan dosis 20 ton/ha belum mampu mengantikan pupuk NPK Phonska dalam meningkatkan pertumbuhan dan produksi ubi jalar secara nyata dalam satu kali musim tanam. Penggunaan kompos jerami secara berkesinambungan diharpkan akan meningkatkan produktivitas dengan meningkatnya bahan organik tanah. Interaksi antara pupuk anorganik dan pupuk organik nyata meningkatkan jumlah daun dan bobot umbi (Setiawan dan Suryantini, 2015).

Berdasarkan hal tersebut diatas, untuk mendapat pertumbuhan dan produksi yang maksimal maka perlu dilakukan percobaan dengan judul Respon Pertumbuhan dan Produksi Tanaman Terung (Solanum melongena) pada berbagai Jenis Tanah dan Penambahan Pupuk NPK Phonska.

\section{Metode Penelitian}

Penelitian ini dilaksanakan di Desa Buntubuda Kecamatan Mamasa Kabupaten Mamasa pada bulan Nopember 2017 sampai dengan bulan Februari 2018 sampai selesai. Bahan yang digunakan adalah benih terung ungu varietas unggul bermutu, pupuk NPK Phonska, polybag.Alat yang digunakan adalah cangkul, sekop, ember, sprayer, pisau, alat ukur (meter), alat timbang, alat tulis menulis.

Penelitian ini menggunakan metode Rancangan Acak Kelompok dengan pola faktorial yang terdiri dari 2 faktor. Faktor pertama jenis tanah (T) dengan 3 taraf : T1 (tanah berpasir), T2 (tanah berhumus) dan T3 (tanah berliat). Faktor kedua adalah pemberian pupuk NPK Phonska (P) dengan 3 taraf : P1 ( 5 g/tanaman), P2 (10g/tanaman) dan $\mathrm{P} 3(15 \mathrm{~g} /$ tanaman $)$. Terdapat 9 kombinasi perlakuan dan terdiri dari 3 ulangan sehingga terdapat 27 unit penelitian dan setiap unit terdiri dari 3 tanaman sehingga keseluruhan terdapat 81 tanaman.

Pelaksanaan penelitian dimulai dengan persiapan media tanam yaitu seminggu sebelum penanaman. Mula-mula tanah dicangkul lalu digemburkan dan dimasukkan dalam polibag. Jarak antar polybag yaitu $50 \mathrm{~cm}$. Selanjutnya masing-masing polybag diberikan perlakuan pemberian pupuk NPK Phonska sesuai dengan waktu pemberian dan dosis perlakuan.

Tanaman terung yang sudah dipindahkan ke polybag, satu minggu sesudah dipindahkan diberikan pupuk NPK phonska sesuai dengan perlakuan, dan pada saat berbunga. Pemeliharaan meliputi penyiangan yang dilakukan 2 minggu sekali dengan mencabut gulma yang tumbuh pada pertanaman dan penyiraman yang dilakukan pagi dan sore hari kecuali bila tanah dalam keadaan lembab atau turun hujan.Parameter pengamatan yang diamati meliputi tinggi tanaman, jumlah dau, jumlah cabang, umur berbunga, umur panen, jumlah buah dan berat buah.

\section{Hasil Dan Pembahasan}

\section{Tinggi tanaman}

Pada parameter tinggi tanaman, tidak terdapat perlakuan yang berpengaruh nyata, baik dari faktor jenis tanah maupun dosis pupuk NPK Phonska, namun terdapat salah satu perlakuan yang memberikan hasil terbaik pada perlakuan (T1P3) yaitu dengan jenis tanah berpasir dengan dosis pupuk phonska $15 \mathrm{~g} /$ tanaman dibandingkan dengan rata-rata tinggi tanaman pada perlakuan lainnya dengan rata-rata tinggi tanaman $169,33 \mathrm{~cm}$.

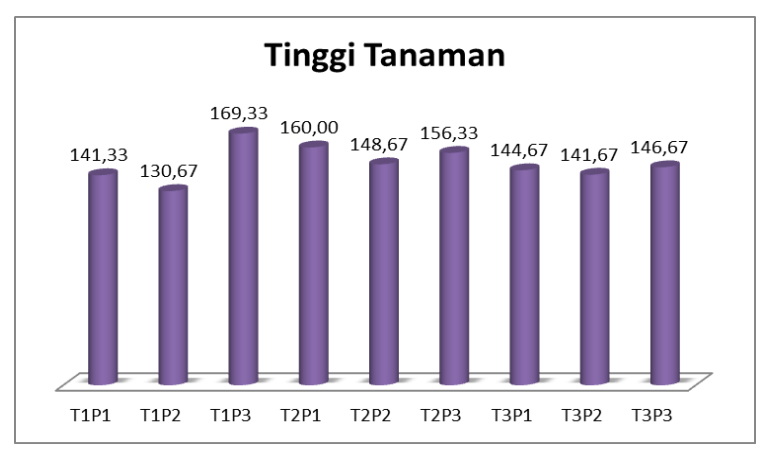

Hal ini menunjukkan pemupukan phonska diduga dapat memberikan kontribusi hara yang dibutuhkan oleh tanaman terung, sehingga dapat menambah ukuran maupun jamlah sel tanaman dan berimplikasi pada pertumbuhan vegetatif tanaman. Dengan demikian unsur hara penting bagi pertumbuhan tanaman. Hal ini sesuai dengan pernyataan Leiwakabessy dan Sutandi dalam Sihombing (2003), bahwa unsur hara 
adalah bahan yang diberikan pada tanaman secara langsung maupun tidak langsung, guna mendorong pertumbuhan tanaman, peningkatan produksi, ataupun perbaikan kualitasnya.

\section{Jumlah Daun}

Pada parameter jumlah daun, tidak ada perlakuan yang memberikan pengaruh nyata, tetapi dari rata-rata jumlah daun tanaman, perlakuan T3P2 yaitu tanah berliat dan pupuk NPK Phonska $10 \mathrm{~g} /$ tanaman.memberikan pengaruh terbaik dengan ratarata 284,00 helai.

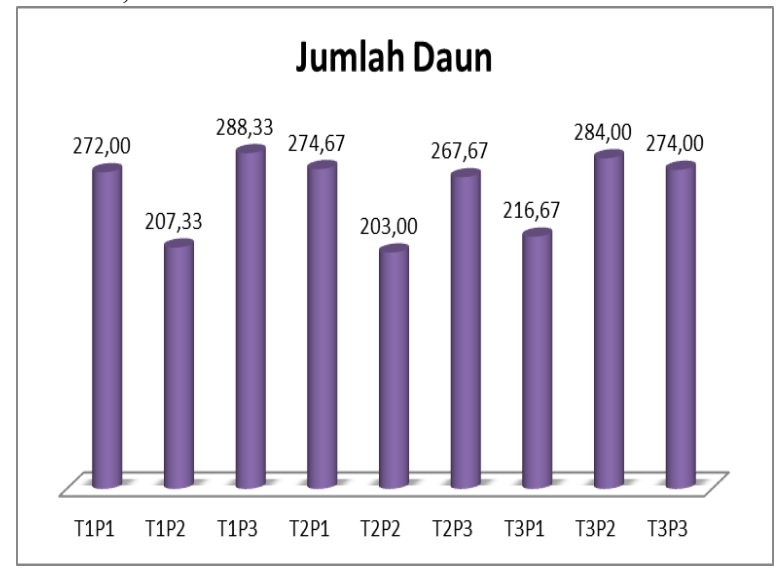

Hal ini diduga karena pemberian pupuk pada tanaman tidak dimanfaatkan oleh tanaman secara optimal. Menurut Lingga (Hamidah, 2009) suatu tanaman akan tumbuh subur bila elemen yang tersedia cukup dan sesuai dengan kebutuhan tanaman, penambahan unsur hara yang berlebihan tidak menghasilkan pertumbuhan vegetatif maupun generatif yang sebanding dengan unsur hara yang diberikan.

\section{Jumlah Cabang}

Hasil penelitian menunjukkan bahwa perlakuan T1P3 yaitu jenis tanah berpasir dan pupuk NPK Phonska $15 \mathrm{~g} /$ tanaman memberikan hasil terbaik dengan rata-rata jumlah cabang 44,56.

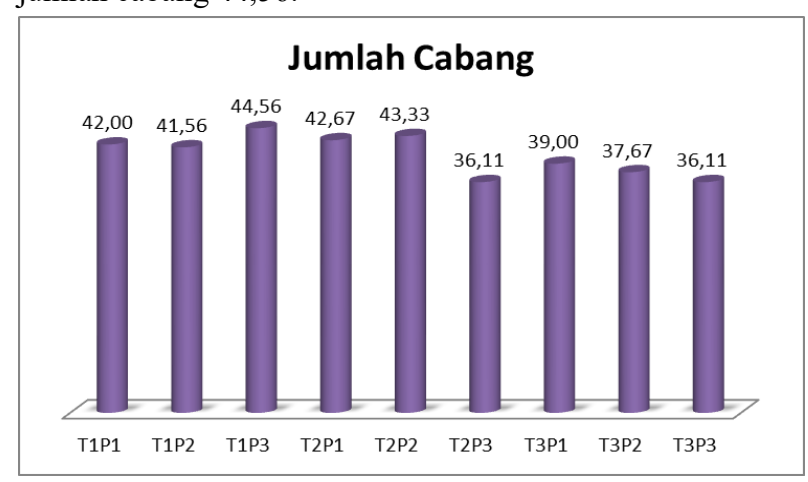

Pupuk NPK Ponska 15 g/tanaman (P3) menghasilkan pertumbuhan yang lebih baik dibandingkan pupuk phonska $5 \mathrm{~g} / \operatorname{tanaman}(\mathrm{P} 1)$ maupun pupuk phonska $10 \mathrm{~g}$ /tanaman (P2). Hal ini menunjukkan bahwa pemberian dosis $15 \mathrm{~g}$ /tanaman pupuk NPK pada tanaman terung mampu memperbaiki dan menambah unsur hara dalam tanah yang diperlukan untuk pertumbuhan tanaman, sehingga perkembangan akar akan menjadi lebih baik sehingga unsur hara yang diserap lebih banyak. Oleh karena itu kebutuhan tanaman akan unsur hara dapat dipenuhi sehingga pemberian pupuk majemuk NPK sangat diperlukan untuk pertumbuhan vegetatif (Angga, 2008). Adhadiyanto (2012) menjelaskan bahwa, peningkatan tinggi tanaman, diameter tajuk, jumlah cabang, jumlah daun, dan luas daun merupakan hasil dari aktifitas pembelahan sel dan pemanjangan sel yang merupakan pertumbuhan diatas tanah.

\section{Umur Berbunga}

Pada paremeter umur berbunga, perlakuan dosis pupuk NPK Phonska $15 \mathrm{~g} /$ tanaman memberikan pengaruh yang nyata terhadap tanaman terung.Rata-rata hasil pengamatan umur berbunga disajikan pada Tabel Lampiran di bawah ini. Pada sidik ragam menunjukkan bahwa perlakuan tanah berhumus (T2) dan pemberian NPK Phonska $15 \mathrm{~g} /$ tanaman yang berpengaruh nyata terhadap umur berbunga terung. Rata rata umur berbunga disajikan pada tabel dibawah ini ;

\begin{tabular}{|c|c|c|c|c|c|}
\hline \multirow[t]{2}{*}{$\begin{array}{l}\text { Jenis } \\
\text { Tanah }\end{array}$} & \multicolumn{5}{|c|}{ Rata - } \\
\hline & $\mathrm{P} 1$ & $\mathrm{P} 2$ & P3 & & Taraf $\alpha 0,05$ \\
\hline $\mathrm{T} 1$ & 25,00 & 29,00 & 28,00 & $27,33^{\mathrm{ab}}$ & 2,29 \\
\hline $\mathrm{T} 2$ & 23,00 & 24,00 & 31,00 & $26,00^{\mathrm{a}}$ & \\
\hline \multirow[t]{2}{*}{$\mathrm{T} 3$} & 21,00 & 26,00 & 26,00 & $24,33^{\mathrm{a}}$ & \\
\hline & 23,00 & 26,33 & 28,33 & & \\
\hline
\end{tabular}

Hal ini diduga karena kandungan unsur $\mathrm{P}$ pada macam pupuk phonska lebih efisien yang diserap tanaman sehingga tidak kelebihan unsur atau kekurangan unsur tersebut sehingga tepat digunakan untuk mempercepat pemunculan bunga.Saat berbunga berkaitan erat dengan pemenuhan unsur hara terutama unsur phospat (P) yang berfungsi untuk mendorong tanaman masuk ke fase generatif. Fase generatif ditandai dengan terbentuknya primordial bunga dan berkembang menjadi bunga yang siap mengadakan penyerbukan (Yunus dan Tri haryanto dalam Johan Sasongko, 2010).Pembungaan merupakan masa transisi tanaman dari fase vegetatif menuju fase generatif yaitu dengan terbentuknya kuncup-kuncup bunga. Pada umumnya proses fisiologis dan morfologis yang mengarah fotoperiode (panjang hari) dan temperatur (Gardner, et al., dalam Johan Sasongko, 2010).

\section{Umur Panen}

Hasil penelitian menunjukkan bahwa perlakuan jenis tanah dan pemberian pupuk NPK Phonska pada tanaman terung tidak memberikan pengaruh nyata, 
namun rata-rata umur panen menunjukkan T2P2 (tanah berhumus dan pupuk NPK Phonska 10g/tanaman) memberikan hasil terbaik dengan rata-rata 67,56 hari

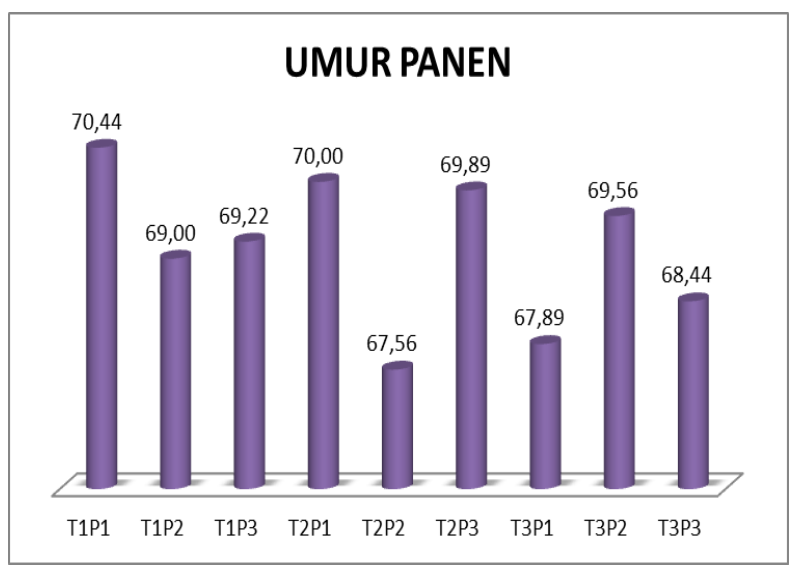

Pemberian pupuk pada tanaman terung telah dapat memenuhi kebutuhan tanaman sehingga dapat mempercepat umur panen tanaman terung. Menurut Sarief dalam Leo Noza dkk (2014), menyatakan bahwa P berperan dalam proses respirasi, fotosintesis dan metabolisme tanaman sehingga mendorong laju pertumbuhan tanaman termasuk umur panen.

Hal ini juga membuktikan bahwa pemberian pupuk dengan optimal secara nyata akan meningkatkan sumbangan hara terhadap tanah. Menurut Winarso (2005), fosfor sangat berpengaruh dalam proses pertumbuhan dan pembentukan hasil, dimana fosfor berfungsi dalam transfer energi dan proses fotosintesis.

\section{Berat Buah}

Hasil penelitian menunjukkan bahwa tidak terdapat perlakuan yang berpengaruh nyata terhadap berat buah terung, demikian juga pada interaksinya tidak memberikan pengaruh yang nyata, namun perlakuan T2P2 yaitu jenis tanah berhumus dan pemberian pupuk NPK Phonska $10 \mathrm{~g} /$ tanaman memberikan hasil terbaik dengan rata-rata $763,33 \mathrm{~g}$.

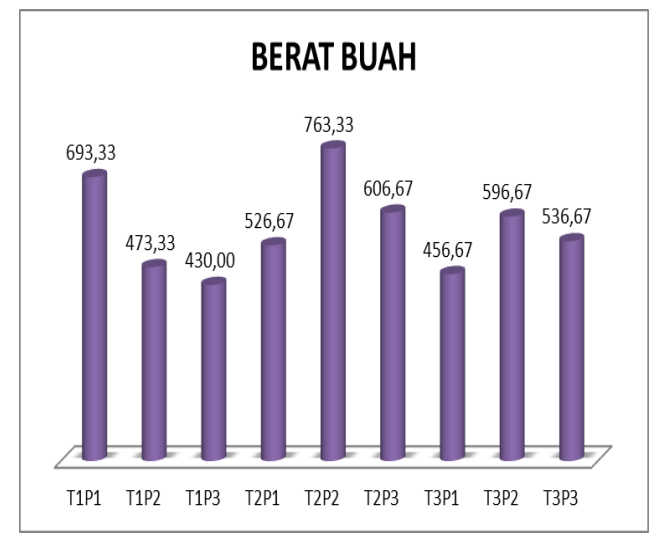

Pada parameter berat buah di atas dapat dijelaskan bahwa rata-rata berat buah terung terberat terdapat pada perlakuan tanah berhumus dengan dosis
NPK pupuk phonska $10 \mathrm{~g} /$ tanaman untuk semua pengamatan dibandingkan dengan rata-rata berat buah pada perlakuan NPK pupuk phonska lainnya. Penelitian Lubis (2004) menyatakan bahwa pemberian pupuk NPK Phonska berpengaruh nyata terhadap berat buah persampel dan produksi buah perplot. Hal ini mungkin disebabkan peranan unsur hara makro yang dikandung pupuk NPK Phonska, dimana unsur - unsur tersebut mempunyai fungsi masingmasing dalam proses metabolisme tumbuhan.

Secara teoritis menyatakan bahwa unsur hara $\mathrm{N}$ berperan dalam pembentukan klorofil yang berguna dalam proses fotosintetis, dimana apabila fotosintesis lancar maka semakin banyak pula karbohidrat yang akan dihasilkan. Menurut Lingga dalam Lubis (2004) bahwa unsur hara $\mathrm{P}$ berperan sebagai bahan dasar pembentukan protein untuk menhasilkan energi ATP dan ADP, dimana energi ini dibutuhkan dalam proses metabolisme untuk pembentukan asam amino, tepung, lemak dan senyawa organik lainnya. Sedangkan unsur hara $\mathrm{K}$ berperan membantu pembentukan protein dan kaebohidrat sekaligus memperkuat tubuh tanaman seperti daun, bunga dan buah sehingga tidak mudah gugur. Selain itu unsur K juga dpat meningkatkan kualitas hasil buah.

\section{Jumlah Buah}

Hasil penelitian menunjukkan perlakuan T1P3 yaitu jenis tanah berpasir dan pupuk NPK $15 \mathrm{~g} /$ tanaman memberikan hasil terbaik dibandingkan perlakuan lainnya dengan rata-rata jumlah buah 29,33.

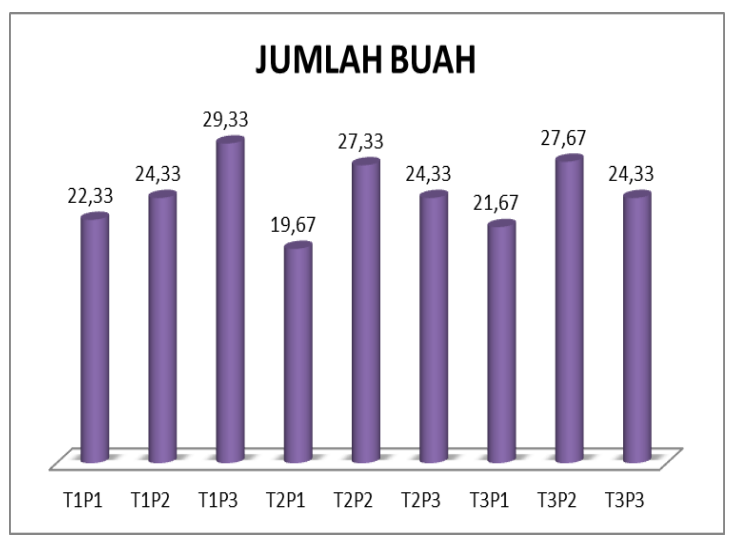

Pada parameter jumlah buah, dijelaskan bahwa rata-rata jumlah buah terung terdapat pada perlakuan jenis tanah berpasir dengan dosis pupuk NPK phonska $15 \mathrm{~g} /$ tanaman menjadi perlakuan terbaik dibandingkan dengan rata-rata jumlah buah pada perlakuan NPK pupuk phonska lainnya.

Jumlah buah pada perlakuan $15 \mathrm{~g} /$ tanaman lebih banyak dibanding lainnya. Hal ini disebabkan oleh terpenuhinya unsur hara pada saat pembentukan buah. Hal ini senada dengan pernyataan Onggo (2001), bahwa pertumbuhan tanaman yang baik membutuhkan hara yang lengkap, penggunaan hara yang tidak lengkap mempengaruhi keseimbangan hara yang dapat diserap dan mengurangi efektivitas serapan hara. Pupuk 
majemuk lengkap dalam bentuk NPK pupuk phonska dapat meningkatkan proses fisiologi berakibat pada peningkatan produk yang dihasilkan yang pada tanaman tomat diekspresikan pada bagian generatif, yaitu buah, baik pada jumlah buah yang dapat terbentuk maupun ukurannya.

\section{Kesimpulan}

Pada penelitian ini dapat disimpulkan bahwa tidak terdapat interaksi jenis tanah dengan penambahan pupuk NPK Phonska yang memberikan pengaruh nyata terhadap parameter tinggi tanaman, jumlah daun, jumlah cabang, umur berbunga, umur panen, berat buah, dan jumlah buah. Tidak terdapat perlakuan jenis tanah yang berpengaruh nyata terhadap semua parameter.Pemberian pupuk NPK Phonska dengan dosis $15 \mathrm{~g} /$ tanaman memberikan hasil yang berpengaruh nyata pada parameter umur berbunga.

\section{Daftar Pustaka}

Anonim, 2003. Teknologi Pengembangan Pertanian Organik. Dinas Pertanian Tanaman Pangan dan Hortikultura Provinsi Sulawesi Selatan

Arsyad. S. 2010. Konservasi Tanah dan Air. IPB Press. Bogor. De Boodt, M. and D. Verdonck. 1972. The Properties of Substrates In Horticulture. Acta Horticultural. 26:37-44.

Hakim, N.; M.Y. Nyakpa; A.M. Lubis; S.G. Nugroho; M.R. Saul; M.A. Diha; G.b. Hong dan H.H. Bailey. 1986. Dasar-Dasar Ilmu Tanah. Universitas Lampung. Bandar Lampung. 258 hlm.

Hanafiah, K. A. 2007. Dasar-dasar Ilmu Tanah. Jakarta : PT. Raja Grafindo Persada.

Hartman, H.T dan D.E. Kester. 1983. Plant Propagation Principle and Practise. Prentice Hall Internasional Inc. Engelwoods Clifs New Jersey.

Islami, T. dan W.H. Utomo. 1995. Hubungan Tanah, Air dan Tanaman. IKIP Semarang Press.

Karim Fahri, Nikmah Musa, Fitriah S. Jamin Respon Pertumbuhan Dan Produksi Tanaman Terung (Solanum Melongena L.) Terhadap Perlakuan Pupuk Phonska

Kaya, E. 2013. Pengaruh Kompos Jerami Dan Pupuk Npk Terhadap N-Tersedia Tanah, Serapan-N, Pertumbuhan, Dan Hasil Padi Sawah (Oryza Sativa L). Agrologia, Vol. 2, No. 1, April 2013, Hal. 43-50. Jurusan Budidaya Pertanian Fakultas Pertanian Universitas Pattimura
Loveless, A.R. 1987. Prinsip-Prinsip Biologi Tumbuhan untuk Daerah Tropik. Gramedia, Jakarta. 408 hlm.

Mayasari. 2015. Tanah Liat : Pengertian, Proses, Ciriciri dan Jenisnya.Ilmu Geografi. https://ilmugeografi.com/ilmubumi/tanah/tanah-liat. Diakses pada Minggu, 22 April 2018

Munir, M. 1996. Tanah-Tanah Utama Indonesia. Karakteristik, Klasifikasi, dan pemanfaatannya. PT. Dunia Pustaka Jaya, Jakarta.346 hlm.

Mutya Alia, 2011. Pengaruh Pupuk Anorganik Dan Pupuk Organik Terhadap Produksi Dan Kualitas Ubi Jalar (Ipomoea Batatas (L.) Lam) Dan Sifat Kimia PodsOlik Jasinga.Program Studi Manajemen Sumberdaya Lahan Departemen Ilmu Tanah Dan Sumberdaya Lahan Fakultas Pertanian Institut Pertanian Bogor

Nazaruddin, 2000. Budidaya dan Pengaturan Panen Sayuran Dataran Rendah. Penebar Swadaya. Jakarta.

Pirngadi, S. dan S. Abdulrachman. 2005.Pengaruh Pupuk Majemuk NPK (15-15-15) Terhadap Pertumbuhan Dan Hasil Padi Sawah. Jurnal Agrivigor 4: 188-197.

Setiawan dan Suryantini, 2015. Peningkatan Produktivitas Beberapa Varietas Lokal Ubi Jalar (Ipomoea Batatas L.) Dengan Pengunaan Pupuk Organik Alami Dan Pupuk Buatan (N, P Dan K).Fakultas Pertanian, Universitas Panca Bhakti

Sunarjono, Hendro. 2013. Bertanam 36 jenis Sayur/ Penebar Swadaya. Jakarta

Soepardi, G. 1079. Sifat dan Ciri Tanah. Proyek Peningkatan dan Pengembangan Perguruan Tinggi, IPB. Bogor.591 hlm.

Sarief, E.S. 1986 Ilmu Tanah Pertanian. Pustaka Buana. Bandung

Soetasad. A.A dan Sri Muryanti. 2012. Budi Daya Terung Lokal dan Terung Jepang.

Thompson and Troeh. 1978. Soil and Soils Fertility. Mac Millan Publishing Co., New York. 698 p.

Tsao Dan Lo Dalam "Vegetables: Types and Biology". Handbook of Food Science, Technology, and EngineeringolehYiu H. Hui (2006). CRC Press

Wahyu Hendro Wibowo.2016. dasar pertanian. http://dasarpertanian.blogspot.co.id/2017/04/inilahpengertian-tanah-humus-yang.html. Diakses pada Minggu 22 April 2018. 